\title{
Article
}

\section{Green Manure Amendment Can Reduce Nitrogen Fertilizer Application Rates for Oilseed Rape in Maize-Oilseed Rape Rotation}

\author{
Chiming Gu ${ }^{1,+}$, Wei Huang ${ }^{2,+}$, Yue Li ${ }^{1}$, Yinshui Li ${ }^{1}$, Changbin $\mathrm{Yu}^{1}{ }^{1}$, Jing Dai ${ }^{1}$, Wenshi Hu ${ }^{1}$, Xiaoyong Li ${ }^{1}$, \\ Margot Brooks ${ }^{3}{ }^{(\mathbb{D}}$, Lihua Xie ${ }^{1}$, Xing Liao ${ }^{1, *}$ and Lu Qin ${ }^{1, *}$ \\ 1 Key Laboratory of Biology and Genetic Improvement of Oil Crops, Oil Crops Research Institute of the \\ Chinese Academy of Agricultural Sciences, Ministry of Agriculture of China, Wuhan 430062, China; \\ guchiming@foxmail.com (C.G.); liyue1231122@126.com (Y.L.); lysh@webmail.hzau.edu.cn (Y.L.); \\ cbyu123@163.com (C.Y.); daijing@caas.cn (J.D.); huws@webmail.hzau.edu.cn (W.H.); \\ dashuai_17@163.com (X.L.); xielh@oilcrops.cn (L.X.) \\ 2 Huanggang Academy of Agricultural Sciences, Huanggang 438000, China; hw_hgaas@163.com \\ 3 Department of Biochemistry and Microbiology, Rhodes University, Grahamstown 6140, South Africa; \\ brooksmargs@yahoo.co.uk \\ * Correspondence: liaox@oilcrops.cn (X.L.); qinlu-123@126.com (L.Q.) \\ $\dagger$ These authors contributed equally to this work and should be considered as co-first authors.
}

Citation: Gu, C.; Huang, W.; Li, Y.; Li, Y.; Yu, C.; Dai, J.; Hu, W.; Li, X.; Brooks, M.; Xie, L.; et al. Green Manure Amendment Can Reduce Nitrogen Fertilizer Application Rates for Oilseed Rape in Maize-Oilseed Rape Rotation. Plants 2021, 10, 2640. https://doi.org/10.3390/ plants10122640

Academic Editors: Othmane Merah, Purushothaman Chirakkuzhyil Abhilash, Magdi T. Abdelhamid, Hailin Zhang and Bachar Zebib

Received: 15 October 2021

Accepted: 18 November 2021

Published: 1 December 2021

Publisher's Note: MDPI stays neutral with regard to jurisdictional claims in published maps and institutional affiliations.

Copyright: () 2021 by the authors. Licensee MDPI, Basel, Switzerland. This article is an open access article distributed under the terms and conditions of the Creative Commons Attribution (CC BY) license (https:// creativecommons.org/licenses/by/ $4.0 /)$.
Abstract: Excessive use of chemical fertilizers has led to a reduction in the quality of arable land and environmental pollution. Using green manure to replace chemical fertilizers is one of the most effective solutions. To study the effect of green manure on the requirement for nitrogen fertilizer in oilseed rape, a field experiment with maize-oilseed rape rotation was conducted. Green manure was intercropped between rows of maize and returned after the maize harvest, with no green manure intercropped as control. Different nitrogen fertilizer treatments $(0,65 \%, 75 \%$ and $100 \% \mathrm{~N}$ rates, respectively) were applied during the oilseed rape season. The results showed that with a $35 \%$ reduction in nitrogen application rate, the rapeseed grain yield was significantly higher with the maize intercropping with green manure returned to the field than with the maize monocropping treatment at the same nitrogen level. Under conditions of intercropping and return of green manure, compared with the full standard rate of nitrogen fertilizer treatment, a reduction in nitrogen application of $25-30 \%$ in the rape season had no significant effect on rape yield. The agronomic efficiency of nitrogen fertilizer on oilseed rape increased significantly, by $47.61-121 \%$, with green manure incorporation. In addition, green manure incorporation significantly increased the soil organic matter content and the soil-available nitrogen content when chemical nitrogen fertilization was abandoned. Benefit analysis showed that a $25-35 \%$ reduction in chemical nitrogen fertilizer applied to oilseed rape crops could be achieved by intercropping green manure in the maize season before the sowing of rapeseed in the experimental area. In the long-term, this measure would increase nitrogen utility, reduce production costs, and have concomitant environmental benefits of improving the quality of cultivated land.

Keywords: green manure; nitrogen application; chemical fertilizer reduction; oilseed rape; maizeoilseed rape rotation

\section{Introduction}

Consequential to the continuous increase in the global population, the demand for agricultural products is increasing rapidly. In order to increase yields, the amount of chemical fertilizer used in agricultural production is escalating, while the application of organic fertilizer remains insufficient. The cultivability of arable land deteriorates under longterm chemical fertilizer application, and environmental pollution is prominent [1-3]. The necessity for increasing the input of organic fertilizer is especially urgent worldwide [4-7]. 
Intercropping green manure is a productive planting system that can make full use of sunlight and heat resources, soil moisture, and nutrients. It is a practical measure to produce and utilize green manure and contribute to sustainable agricultural production [8-10]. It is estimated that $15-20 \%$ of food production in the world has involved intercropping [11,12], and it has been widely used in China for centuries $[13,14]$. Intercropping with legumes has a crucial advantage as legumes can fix nitrogen from the air to supply extra nitrogen to the soil for crops, and as high-quality green manure, it is beneficial for soil quality when legume biomass is returned to the field [15,16] (Figure 1).

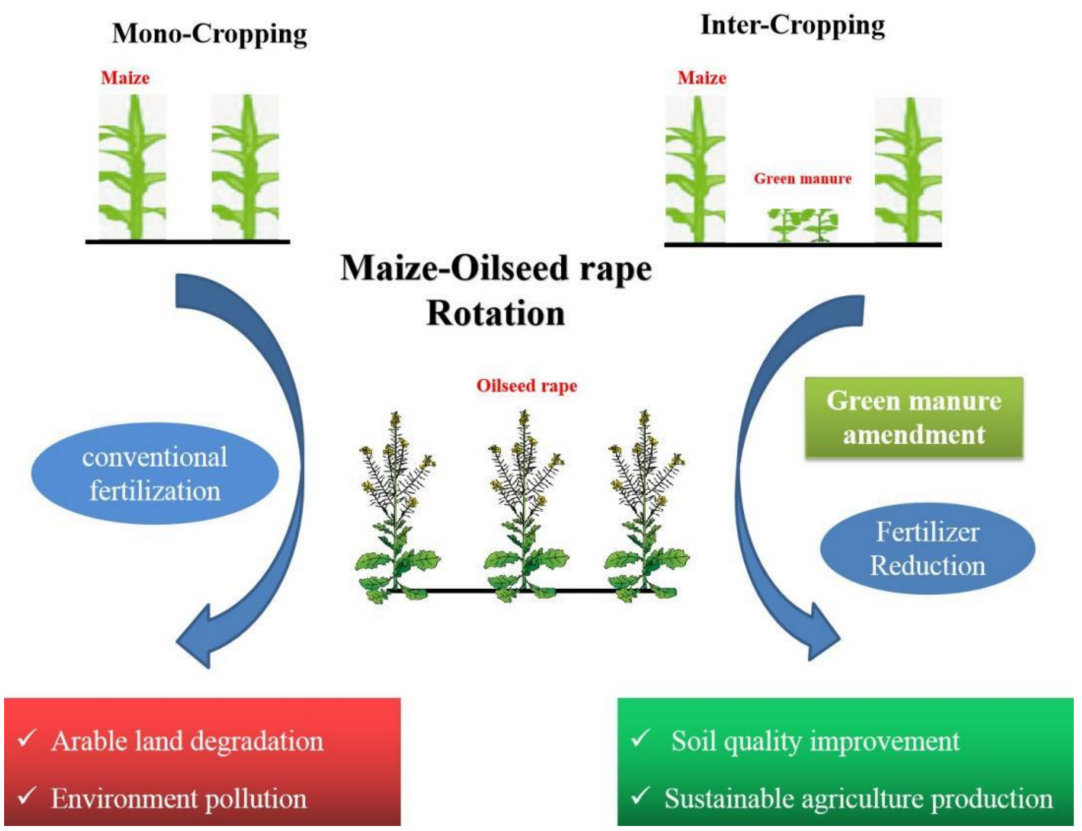

Figure 1. Green manure amendment in maize-oilseed rape rotation.

Oilseed rape is the source of the world's third most consumed edible oil after soybean and palm and is also the primary source of biodiesel [17]. In 2018, the planting area of rapeseed in China was 6.55 million hectares, and the average annual output of rapeseed oil was 6.6 million tons, making it the largest source of edible oil in China [18]. Thus, oilseed rape has a pivotal role in ensuring food security, and increasing the production of rapeseed oil is of strategic significance for ensuring the global supply of edible oil $[19,20]$.

Maize-oilseed rape rotation is widely practiced as a crop rotation system worldwide [8,21]. In this rotation system, intercropping green manure between rows of maize can offer multiple benefits. It rationalizes the planting configuration, facilitates full utilization of resources such as light, heat, water, and nutrients, maximizes the output potential of the land while also providing high-quality green manure for the oilseed rape [22]. In addition, the effect of biological nitrogen fixation by the legumes and the reduction of soil surface evaporation by covering the ground [23]; both present effective ways to reduce the application of chemical fertilizers and increase the seed yield of oilseed rape [24].

However, there are few reports of research on the potential reduction in the requirement for chemical fertilizer that may be achieved by intercropping with legumes in the preceding crop season and supplying green manure for the later season's oilseed rape crop in the maize-oilseed rape rotation systems. We hypothesized that:

(i) legume Labadou (Lablab purpureus (L.) Sweet) facilitates reduction in the need for fertilizer- $\mathrm{N}$ in intercropping systems of maize and oilseed rape;

(ii) growing Labadou in the summer-autumn growing season increases biomass production and fertilizer-N efficiency of winter oilseed rape (Brassica napus L.);

(iii) introducing an intercropping method to maize and oilseed rape rotation systems in dryland decreases $\mathrm{N}$ application rates. 
To test these hypotheses, a maize-oilseed rape rotation field trial was conducted to study the effects of different treatments on the yield of corn and rapeseed and basic soil properties. Maize intercropping with leguminous green manure (IC) and maize monocropping $(\mathrm{MC})$ planting configurations were set up for the maize season, and different chemical nitrogen doses were set based on the standard local rapeseed nitrogen application rate $\left(\mathrm{N}, 169 \mathrm{~kg} \mathrm{ha}^{-1}\right)$.

\section{Results}

\subsection{Analysis of the Meteorological Data of the Experimental Site}

The rainfall, temperature, and duration of sunshine at the experimental site during the experimental periods are shown in Figure 2. Comparing the two maize seasons (from June to September of each year), the total rainfall, average temperature, and total sunshine hours in 2019 were higher than in 2018. Rainfall, temperature, and total sunshine duration increased by $7.78 \%, 0.37 \%$, and $9.34 \%$, respectively. For the two oilseed rape seasons (from October to May of the following year), the average temperature and total sunshine duration of the second oilseed rape season (2019-2020) was significantly higher, increasing by $9.40 \%$ and 55.64\%, respectively, compared to the first season (2018-2019), and the total rainfall was significantly lower, reduced by $18.82 \%$. As the rainfall in the 2019 maize season was $23.9 \mathrm{~mm}$ higher than in 2018. Still, the average temperature difference between the two seasons was only $0.1^{\circ} \mathrm{C}$, the soil moisture for the second rapeseed season was better than for the first season. While $63.86 \%$ of the total decrease in total rainfall occurred in the second oilseed rape season, the rapeseed was planted with suitable moisture content and did not suffer water damage after emergence.

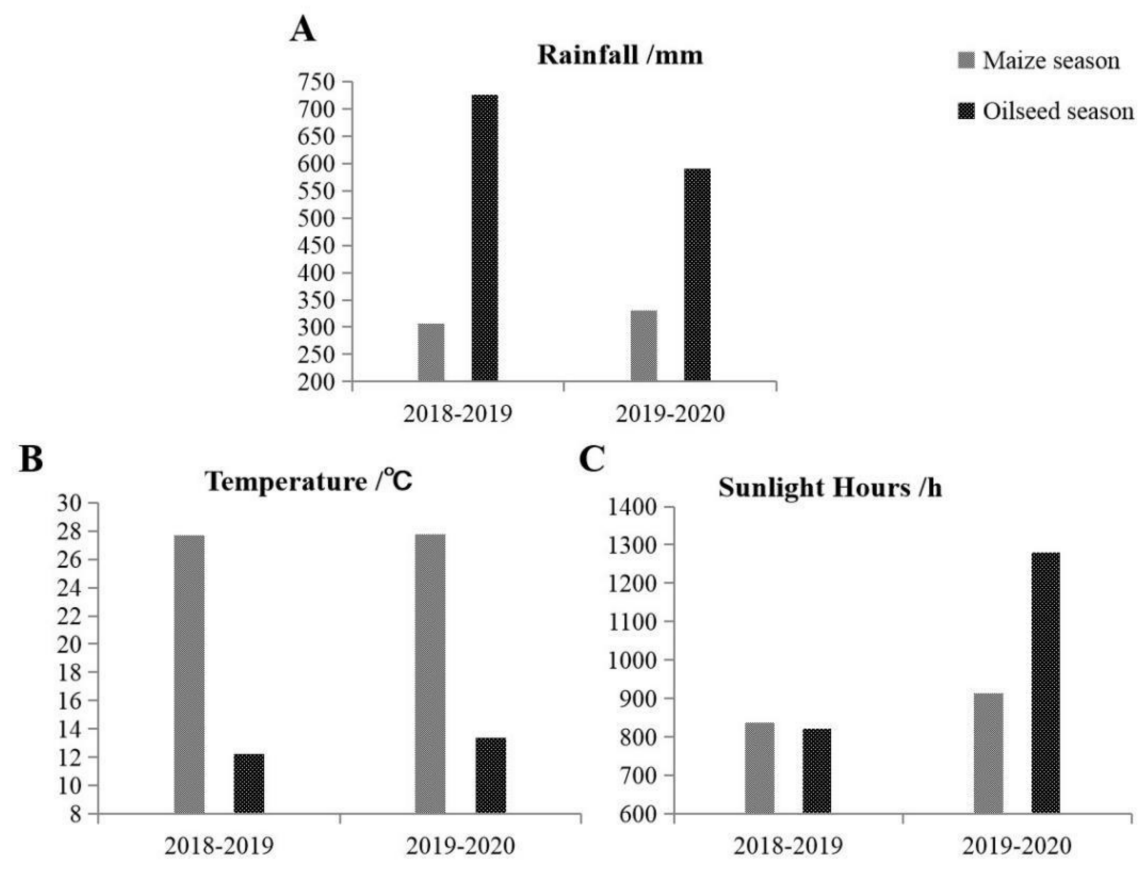

Figure 2. Basic meteorological data of the experimental site during experimental period. (A): Rainfall; (B): Temperature; (C): Sunlight Hours.

\subsection{Effects of Different Treatments on Crop Yield}

During the experimental period, compared with $\mathrm{MC}$, the maize yield of IC showed no significant difference. Intercropping with green manure, or not, during the maize season had no significant effect on the yield of both maize and rapeseed. Green manure yield in IC reached averages of $22.03 \mathrm{t} \mathrm{ha}^{-1}$ (Table 1 ). The effect of green manure combined with different nitrogen application rates on oilseed rape yield is shown in Figure 3. During the experimental period, the rapeseed yield in MC increased significantly with increasing 
nitrogen application. Compared with N0, N application significantly increased the yield of rape in $\mathrm{MC}$, however, there was no significant difference between different $\mathrm{N}$ application rates in IC.

Table 1. Yield of maize, oilseed rape $\left(\mathrm{kg} \mathrm{ha}^{-1}\right)$ and Labadou $\left(\mathrm{t} \mathrm{ha}^{-1}\right)$.

\begin{tabular}{ccccc}
\hline \multirow{2}{*}{ Treatment } & \multicolumn{2}{c}{ 2018-2019 } & \multicolumn{2}{c}{ 2019-2020 } \\
\cline { 2 - 5 } & MC & IC & MC & IC \\
\hline Maize & $5483 \pm 49.81 \mathrm{a}$ & $5425 \pm 131.92 \mathrm{a}$ & $5484 \pm 311 \mathrm{a}$ & $5185 \pm 102 \mathrm{a}$ \\
Oilseed rape & $2322 \pm 186 \mathrm{a}$ & $2302 \pm 310 \mathrm{a}$ & $2558 \pm 390 \mathrm{a}$ & $2785 \pm 527 \mathrm{a}$ \\
Labadou & - & $19.99 \pm 1.76$ & - & $24.07 \pm 2.69$ \\
\hline
\end{tabular}

Note: Different lowercase letters represent the differences between MC and IC.

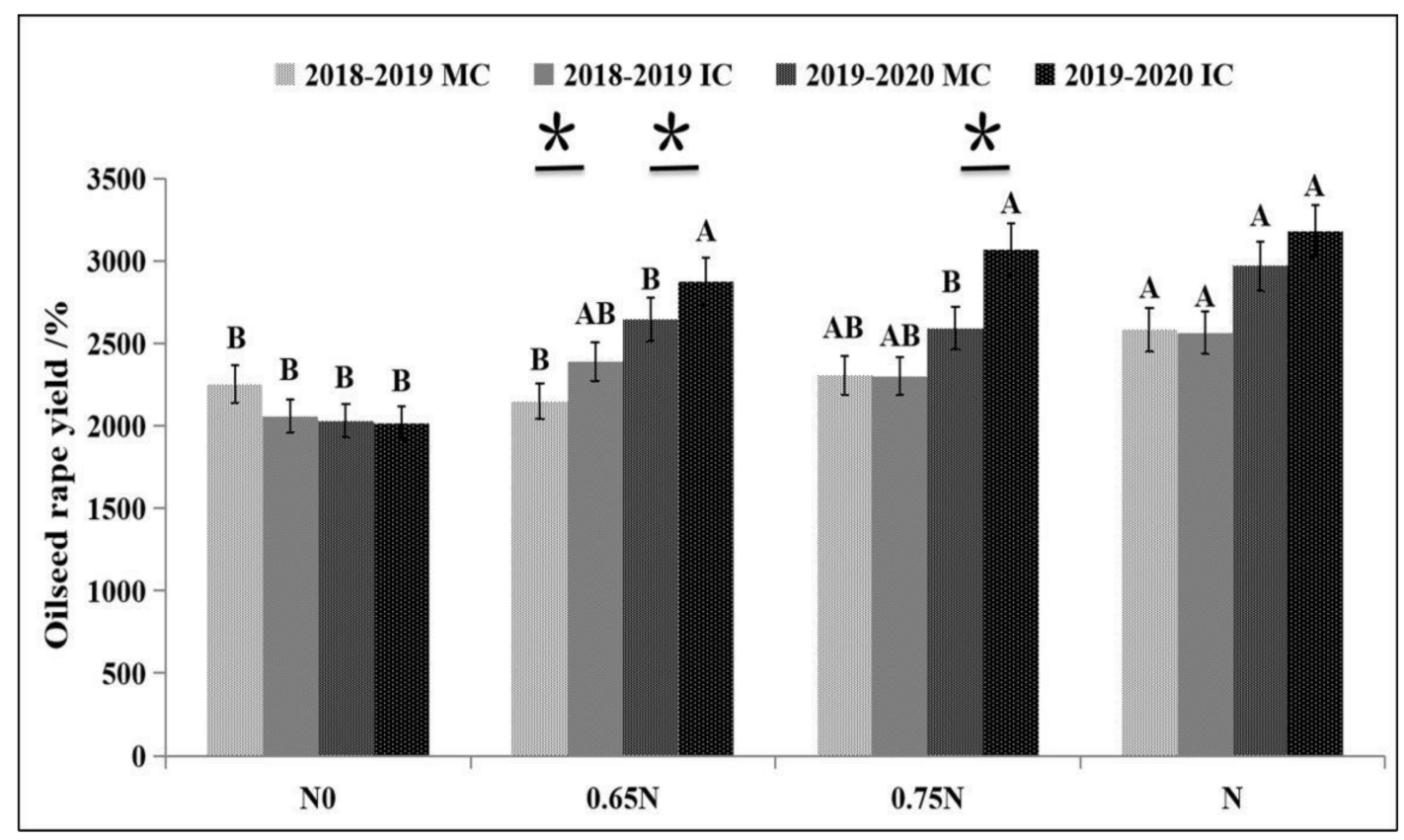

Figure 3. Effects of different treatments on the grain yield of oilseed rape $\left(\mathrm{kg} \mathrm{ha}^{-1}\right)$. Note: ${ }^{*}$ Represents the significant difference between MC and IC at the same nitrogen dose in the same year; capital letters indicate the difference between treatments with different nitrogen doses in the same year and the same mode.

In the first experimental season (2018-2019), compared with $\mathrm{MC}+\mathrm{N}$, the rapeseed yield was significantly reduced by $20.31 \%$ in $\mathrm{MC}+0.65 \mathrm{~N}$, while no significant differences were found under IC. In the second season (2019-2020), compared with MC + N, the rapeseed yield was significantly reduced by $20.12 \%$ and $14.51 \%$ in $\mathrm{MC}+0.65 \mathrm{~N}$ and $\mathrm{MC}+0.75 \mathrm{~N}$, respectively (Figure 3 ). However, there was still no statistically significant decrease found in IC $+0.65 \mathrm{~N}$ and IC $+0.75 \mathrm{~N}$. The rapeseed grain yield with $0.65 \mathrm{~N}$ was significantly higher in IC than in $\mathrm{MC}+0.65 \mathrm{~N}$ by $11.32 \%$ and $8.77 \%$, respectively, in the first and second seasons. In IC $+0.75 \mathrm{~N}$, yield increased significantly by $18.44 \%$ in the second season. The yield components of maize showed no significant differences between MC and IC. No trends were found in oilseed rape component yield among different treatments (Table 2). 
Table 2. Yield components of maize and oilseed rape under different treatments.

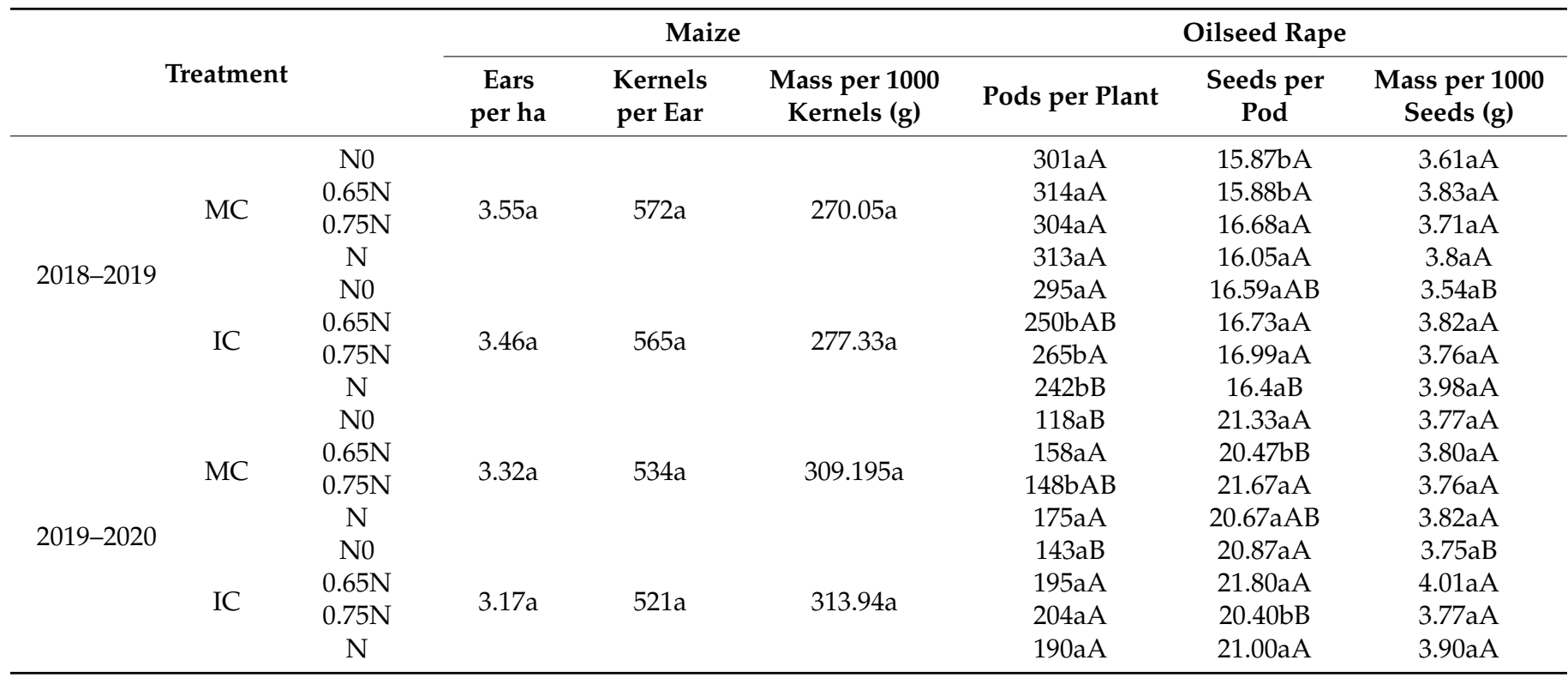

Note: Different lowercase letters represent the significant difference between MC and IC at the same nitrogen dose in the same year; different capital letters indicate the difference between treatments with different nitrogen doses in the same year and the same planting mode.

Results of the analysis of the nitrogen fertilizer agronomic efficiency of rapeseed under different treatments are shown in Table 3. The nitrogen fertilizer agronomic efficiency of oilseed rape with IC was significantly higher than with MC in the two consecutive seasonsby $121 \%$ and $47.61 \%$ in the first and second seasons, respectively.

Table 3. Nitrogen fertilizer agronomic efficiency of oilseed rape under different treatments $\left(\mathrm{kg} \mathrm{kg}^{-1}\right)$.

\begin{tabular}{cccccc}
\hline \multirow{2}{*}{ Treatment } & \multicolumn{2}{c}{2018} & \multicolumn{2}{c}{2019} & Average \\
\cline { 2 - 5 } & MC & IC & MC & IC & - \\
N0 & - & - & - & - & 4.11 \\
$0.65 \mathrm{~N}$ & - & 2.26 & 4.20 & 5.88 & 2.83 \\
$0.75 \mathrm{~N}$ & 0.32 & 1.43 & 3.33 & 6.24 & 3.26 \\
$\mathrm{~N}$ & 1.47 & 2.24 & 4.17 & 5.15 & $5.76 \mathrm{a}$ \\
average & $0.90 \mathrm{~b}$ & $1.98 \mathrm{a}$ & $3.90 \mathrm{~b}$ & 24
\end{tabular}

Note: Different lowercase letters represent the significant difference between MC and IC in the same year.

\subsection{Effects of Different Treatments on Soil Properties}

The effect of green manure under different nitrogen application rates on soil organic matter content is shown in Figure 4. Compared with MC, IC could increase soil organic matter by $27.96 \%$ and $39.81 \%$ in $\mathrm{N} 0,19.80 \%$ and $9.93 \%$ in $0.65 \mathrm{~N}, 15.15 \%$ and $6.52 \%$ in $0.75 \mathrm{~N}$, and $5.56 \%$ and $3.80 \%$ in $\mathrm{N}$ in the first and second seasons, respectively (Figure 4 ). These changes reached significant levels in the first and second seasons in $0.65 \mathrm{~N}$ and $0.75 \mathrm{~N}$. The differences in soil $\mathrm{pH}$ between different treatments are shown in Table 4 . Under both planting modes, the $\mathrm{pH}$ value of $\mathrm{N} 0$ was the highest. However, in this study, the nitrogen application rate and the rotation method had no significant effect on the soil pH (Table 4). 


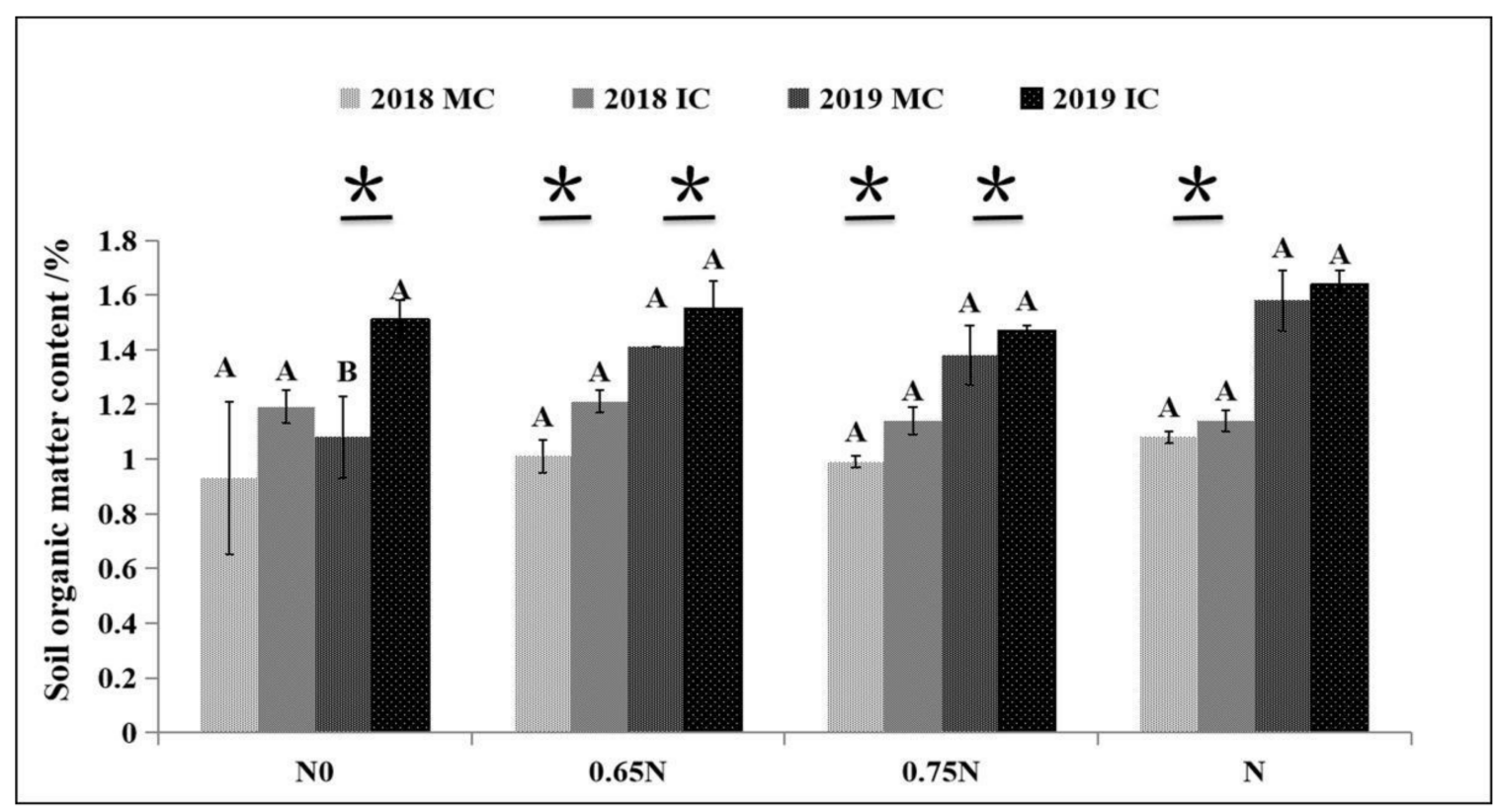

Figure 4. Effects of different treatments on soil organic matter content (\%). Note: ${ }^{*}$ Represents the significant difference between MC and IC at the same nitrogen dose in the same year; different capital letters indicate the difference between treatments with different nitrogen doses in the same year and the same mode; bars below letters represent standard deviation.

Table 4. Effects of different treatments on soil $\mathrm{pH}$.

\begin{tabular}{ccccc}
\hline \multirow{2}{*}{ Treatment } & \multicolumn{2}{c}{2018} & \multicolumn{2}{c}{2019} \\
\cline { 2 - 5 } & MC & IC & MC & IC \\
\hline N0 & $7.53 \pm 0.45 \mathrm{aA}$ & $7.67 \pm 0.35 \mathrm{aA}$ & $7.54 \pm 0.27 \mathrm{aA}$ & $7.77 \pm 0.20 \mathrm{aA}$ \\
$0.65 \mathrm{~N}$ & $7.29 \pm 0.26 \mathrm{aA}$ & $7.44 \pm 0.31 \mathrm{aA}$ & $7.43 \pm 0.26 \mathrm{aAB}$ & $7.37 \pm 0.24 \mathrm{aB}$ \\
$0.75 \mathrm{~N}$ & $7.25 \pm 0.06 \mathrm{aA}$ & $7.57 \pm 0.31 \mathrm{aA}$ & $7.22 \pm 0.06 \mathrm{bB}$ & $7.56 \pm 0.28 \mathrm{aAB}$ \\
$\mathrm{N}$ & $7.50 \pm 0.29 \mathrm{aA}$ & $7.48 \pm 0.26 \mathrm{aA}$ & $7.50 \pm 0.29 \mathrm{aA}$ & $7.51 \pm 0.25 \mathrm{aAB}$ \\
\hline
\end{tabular}

Note: Different lowercase letters represent the significant difference between MC and IC at the same nitrogen dose in the same year; different capital letters indicate the difference between treatments with different nitrogen doses in the same year and the same planting mode.

The differences in the content of soil-available nitrogen between different treatments are shown in Table 5. With an increase in the nitrogen application rate, the soil-available nitrogen content in the same planting mode showed a significant increase. When nitrogen was not applied, the soil-available nitrogen in IC was significantly higher than in MC, for the full duration of the experiment. When the nitrogen dose was reduced by $35 \%$, the soil-available nitrogen content in IC was higher than that in MC both in 2018 and 2019, but this was not significant. The $0.75 \mathrm{~N}$ and $\mathrm{N}$ treatments showed no apparent trends.

Table 5. Effects of different treatments on soil-available nitrogen content $\left(\mathrm{mg} \mathrm{kg}^{-1}\right)$.

\begin{tabular}{ccccc}
\hline \multirow{2}{*}{ Treatment } & \multicolumn{2}{c}{2018} & \multicolumn{2}{c}{2019} \\
\cline { 2 - 5 } & MC & IC & MC & IC \\
\hline N0 & $61.92 \pm 2.37 \mathrm{bB}$ & $78.99 \pm 6.63 \mathrm{aA}$ & $63.65 \pm 2.43 \mathrm{bB}$ & $73.86 \pm 8.90 \mathrm{aAB}$ \\
$0.65 \mathrm{~N}$ & $67.83 \pm 3.69 \mathrm{aB}$ & $71.18 \pm 2.05 \mathrm{aB}$ & $71.91 \pm 3.79 \mathrm{aAB}$ & $73.17 \pm 2.10 \mathrm{aB}$ \\
$0.75 \mathrm{~N}$ & $65.94 \pm 1.42 \mathrm{aB}$ & $76.54 \pm 10.84 \mathrm{aAB}$ & $78.98 \pm 19.30 \mathrm{aAB}$ & $78.44 \pm 7.88 \mathrm{aAB}$ \\
$\mathrm{N}$ & $71.96 \pm 1.42 \mathrm{bA}$ & $81.00 \pm 8.36 \mathrm{aA}$ & $83.49 \pm 16.52 \mathrm{aA}$ & $80.97 \pm 9.87 \mathrm{aA}$ \\
\hline
\end{tabular}

Note: Different lowercase letters represent the significant difference between MC and IC at the same nitrogen dose in the same year; different capital letters indicate the difference between treatments with different nitrogen doses in the same year and the same planting mode. 
The differences in soil-available phosphorus content between different treatments are shown in Table 6. The data showed that both cropping mode and nitrogen fertilizer dose had no significant effect on the soil-available phosphorus content during the entire experimental period.

Table 6. Effects of different treatments on soil-available phosphorus content $\left(\mathrm{mg} \mathrm{kg}^{-1}\right)$.

\begin{tabular}{ccccc}
\hline \multirow{2}{*}{ Treatment } & \multicolumn{2}{c}{2018} & \multicolumn{2}{c}{2019} \\
\cline { 2 - 5 } & MC & IC & MC & IC \\
\hline N0 & $8.18 \pm 0.88 \mathrm{aA}$ & $7.85 \pm 4.19 \mathrm{aA}$ & $7.82 \pm 0.88 \mathrm{aA}$ & $7.49 \pm 2.48 \mathrm{aA}$ \\
$0.65 \mathrm{~N}$ & $8.50 \pm 2.64 \mathrm{aA}$ & $9.48 \pm 0.60 \mathrm{aA}$ & $7.02 \pm 2.65 \mathrm{aA}$ & $9.13 \pm 1.56 \mathrm{aA}$ \\
$0.75 \mathrm{~N}$ & $8.71 \pm 2.39 \mathrm{aA}$ & $9.78 \pm 0.77 \mathrm{aA}$ & $7.38 \pm 2.40 \mathrm{aA}$ & $9.43 \pm 1.57 \mathrm{aA}$ \\
$\mathrm{N}$ & $8.32 \pm 1.29 \mathrm{aA}$ & $9.54 \pm 4.89 \mathrm{aA}$ & $8.71 \pm 1.29 \mathrm{aA}$ & $9.19 \pm 0.63 \mathrm{aA}$ \\
\hline
\end{tabular}

Note: Different lowercase letters represent the significant difference between MC and IC at the same nitrogen dose in the same year; different capital letters indicate the difference between treatments with different nitrogen doses in the same year and the same planting mode.

The difference in soil-available potassium content between different treatments is shown in Table 7. With the increase in nitrogen application rate, the soil-available potassium in MC showed a trend of significantly decreasing. A similar decreasing trend could be seen in IC, but this trend did not reach a significant level. When the full standard nitrogen dose was applied, soil-available potassium was significantly higher in IC than in MC. Under the same dose reduction in nitrogen application, the cropping mode had no significant effect on the soil-available potassium content.

Table 7. Effects of different treatments on content of soil-available potassium $\left(\mathrm{mg} \mathrm{kg}^{-1}\right)$.

\begin{tabular}{ccccc}
\hline \multirow{2}{*}{ Treatment } & \multicolumn{2}{c}{2018} & \multicolumn{2}{c}{2019} \\
\cline { 2 - 5 } & MC & IC & MC & IC \\
\hline $\mathrm{N} 0$ & $194 \pm 51.42 \mathrm{aA}$ & $210 \pm 28.14 \mathrm{aA}$ & $195 \pm 50.94 \mathrm{aA}$ & $211 \pm 36.87 \mathrm{aA}$ \\
$0.65 \mathrm{~N}$ & $178 \pm 35.30 \mathrm{aA}$ & $211 \pm 32.18 \mathrm{a}$ & $179 \pm 34.97 \mathrm{aAB}$ & $211 \pm 33.22 \mathrm{aA}$ \\
$0.75 \mathrm{~N}$ & $167 \pm 30.37 \mathrm{bAB}$ & $206 \pm 12.54 \mathrm{aA}$ & $185 \pm 30.07 \mathrm{aA}$ & $207 \pm 14.61 \mathrm{aA}$ \\
$\mathrm{N}$ & $154 \pm 13.7 \mathrm{bB}$ & $194 \pm 28.57 \mathrm{aA}$ & $163 \pm 13.57 \mathrm{bB}$ & $195 \pm 30.54 \mathrm{aA}$ \\
\hline
\end{tabular}

Note: Different lowercase letters represent the significant difference between MC and IC at the same nitrogen dose in the same year; different capital letters indicate the difference between treatments with different nitrogen doses in the same year and the same planting mode.

\section{Discussion}

\subsection{Effects of Intercropping Combined with Nitrogen Application on Crop Growth}

Existing studies have shown that rapeseed yield may vary according to the different effects of previous crop types [25-27]. In our maize-rapeseed rotation study, intercropping green manure had no significant effect on maize yield. However, it significantly reduced the nitrogen fertilizer required in subsequent oilseed rape crops. Under the condition of $35 \%$ nitrogen reduction, the average yield of oilseed rape after IC was significantly higher than after maize monocropping, by 10.05\%. Because of root nodule nitrogen fixation and the nitrogen transfer capability of leguminous plants, and the concomitant suppression of the soil weed seed bank to decrease competition with crops for nutrients [28], legume intercropping with gramineous crops can promote the absorption and utilization of nitrogen in gramineous crops and significantly increase yield [22]. Compared with monocropping, intercropping legume green manure increased the yield of proso millet by 13.9-50.1\% [29] and maize by 35\% [22]. As reported, approximately two-thirds of 11 rice cultivars [30] and black oats [31] showed significantly increased yields with intercropping, compared with monocropping.

However, many researchers have found different results. In our study, even with a $25-35 \%$ reduction in nitrogen fertilizer, the rapeseed yield was not significantly different from the yield with the standard nitrogen dose when under the maize-intercropping mode, 
indicating that green manure in the previous maize intercropping could substitute $25-35 \%$ of nitrogen fertilizer for oilseed rape production in the experimental site.

The amount of $\mathrm{N}$ transferred from a legume to associated crops is a subject of considerable controversy. It varies depending on conditions that impact legume $\mathrm{N}$-fixation, such as legume species, symbiotic performance, and agronomic factors, such as weather conditions [32]. In our research, total rainfall, average temperature, total sunshine hours, and especially rainfall distribution, influenced oilseed rape seedling growth and yield (Figure 2). In this experiment, the legume green manure in the maize-oilseed rape rotation also significantly impacted the oilseed rape nitrogen utilization. Compared with monocropping, the agronomic efficiency of rapeseed nitrogen fertilizer utilization under intercropping could be significantly increased by $121 \%$ and $47.61 \%$ in the first and second seasons, respectively.

The application rate of nitrogen fertilizer has a considerable influence on the yield and quality of rapeseed. Frugal application of nitrogen fertilizer has a critical role in saving production costs and improving the yield and quality of oilseed rape [33]. At present, the existing research on green manure pertains mainly to grain crops or others with higher economic value $[22,24,31,34]$. Studies have rarely associated the application of green manure with the reduction of nitrogen fertilizer and nitrogen utilization efficiency of oilseed rape. Prior studies found that compared with the sole application of chemical fertilizers, combining with green manure significantly increased the nitrogen accumulation and the nitrogen fertilizer agronomic efficiency of spring maize [16] and rice [35].

\subsection{Effects of Intercropping Combined with Nitrogen Application on Soil Properties}

In this experiment, after two years of continuous planting and return of green manure, the soil organic matter significantly increased by $3.80 \%$ to $39.81 \%$. The effect of planting and returning legume green manure on soil properties is closely related to the soil property background value [35]. It has been found that organic matter accumulates faster in soil with a lower background organic matter value after green manure amendment, while in the short term (1-2 years), returning green manure has no apparent impact on soil with a higher organic matter background value $[35,36]$. The soil in this study had a relatively low organic matter background value of about $1.46 \%$. Thus, with a lower background value, soil organic matter significantly increased. Generally, the long-term application of green manure results in a significant increase in soil organic matter, but in the short term, the effect of turning green manure into the field varies due to differences in soil, climate, and farming systems $[37,38]$. In addition, whether green manure amendment has any significant impact on soil organic matter depends upon the duration of application, the varieties, and the dose of green manure, among other factors [39,40]. In general, because the soil's available nutrients change rapidly in the soil, they will be affected by many factors, including farming methods, fertilizer types, fertilizer application methods, crop growth, and rainfall $[37,38,40]$. Thus, the analysis of changes in soil-available nutrients must consider multiple factors.

Studies have shown that green manure amendment can increase the content of available nitrogen [34], available phosphorus [37,41], and available potassium [1] in soil. In our study, when nitrogen fertilizer application was abandoned, the soil-available nitrogen of IC increased significantly for the entire duration of the experiment. However, there were no obvious trends for soil $\mathrm{pH}$, soil-available phosphorus, and potassium content. The input of green manure or organic fertilizer can increase the activity of soil microorganisms [35,42], which in turn activates the soil's nitrogen, phosphorus, and potassium nutrients and micronutrient elements [41,43,44], leading to increased yield [45]. In some studies, even a reduction in the amount of chemical fertilizer applied had no significant effect on the soil nutrient content of the farmland after green manure amendment $[36,46]$. Interestingly, in our study the input of green fertilizer had no effect on phosphorus and potassium content, and the precise reason needs to be discovered in the subsequent work. 


\subsection{Benefit Analysis}

We calculated the benefit under different treatments based on local maize and oilseed rape prices and labor costs. The results of the benefit analysis showed that although the intercropping would increase seed and labor costs, the overall benefit of intercropping would still be slightly higher than monocropping due to a reduction in the nitrogen fertilizer application dose by $25-35 \%$ (Table 8 ). More importantly, the intercropping would also increase the soil organic matter content and improve the soil quality. There would be concomitant environmental benefits in the long term, due to the improved quality of cultivated land.

Table 8. Analysis of benefits (CNY ha $\left.{ }^{-1}\right)$.

\begin{tabular}{|c|c|c|c|c|c|c|c|c|c|}
\hline \multirow{2}{*}{\multicolumn{2}{|c|}{ Treatment }} & \multicolumn{2}{|c|}{ Production } & \multirow{2}{*}{ Total Income } & \multicolumn{4}{|c|}{ Cost } & \multirow{2}{*}{ Benefits } \\
\hline & & Maize & Oilseed Rape & & Seed & Fertilizer & Labor & Other & \\
\hline \multirow{3}{*}{ IC } & $0.65 \mathrm{~N}$ & & 7187 & 18134 & 850 & 3450 & 1500 & 500 & 11,834 \\
\hline & $0.75 \mathrm{~N}$ & 10,967 & 7347 & 18294 & 850 & 3524 & 1500 & 500 & 11,920 \\
\hline & $\mathrm{N}$ & & 8327 & 19274 & 850 & 3707 & 1500 & 500 & 12,717 \\
\hline \multirow{3}{*}{ MC } & $0.65 \mathrm{~N}$ & & 7899 & 18509 & 1000 & 3450 & 1650 & 500 & 11,909 \\
\hline & $0.75 \mathrm{~N}$ & 10,610 & 8055 & 18665 & 1000 & 3524 & 1650 & 500 & 11,991 \\
\hline & $\mathrm{N}$ & & 8610 & 19220 & 1000 & 3707 & 1650 & 500 & 12,363 \\
\hline
\end{tabular}

\section{Materials and Methods}

\subsection{Experimental Site}

The experimental site is located in Meijiadun Village, Ducheng Town, Huangzhou District, Huanggang City, Hubei Province, China. It is $114^{\circ} 88^{\prime}$ east longitude, $30^{\circ} 43^{\prime}$ north latitude, and $26.7 \mathrm{~m}$ altitude. It has a typical humid subtropical monsoon climate, with abundant water and heat resources. The rainfall is mainly concentrated from April to August. The annual average rainfall is $(1287 \pm 305) \mathrm{mm}$, the annual average temperature is $(17.7 \pm 0.5){ }^{\circ} \mathrm{C}$, the annual average sunshine duration is $1900 \mathrm{~h}$, and the frost-free period is $260 \mathrm{~d}$. The soil texture is sandy loam and had the following chemical characteristics: SOM was $1.46 \%$, $\mathrm{pH}\left(\mathrm{H}_{2} \mathrm{O}\right.$ : soil = 5:1) was 7.53, alkali-hydrolyzable nitrogen was $61.43 \mathrm{mg} \mathrm{kg}^{-1}$, available phosphorus was $5.07 \mathrm{mg} \mathrm{kg}^{-1}$, and available potassium was $101.87 \mathrm{mg} \mathrm{kg}^{-1}$.

\subsection{Experimental Design}

The experimental design was based on the split zone test. The primary strategy was to compare the effect of green manure intercropping with monocropping, while the secondary strategy was to measure this interaction with varying fertilizer doses (only for oilseed rape). For the green manure intercropping treatment (IC), wide and narrow row spacings were adopted in the maize season, and Labadou (Lablab purpureus (L.) Sweet), leguminous green manure, was interplanted between the wide rows of maize (Zea mays L.), the variety of maize is zhengdan69, was grown for grain. The width between maize rows was $160 \mathrm{~cm}$ and between plants was $15 \mathrm{~cm}$ for the wide rows and $40 \mathrm{~cm} \times 15 \mathrm{~cm}$ for the narrow rows. The row spacing for the maize monocropping treatment (MC) was $100 \mathrm{~cm} \times 15 \mathrm{~cm}$ (Figure 5). The sowing rate of maize was $37.5 \mathrm{~kg} \mathrm{ha}^{-1}$, and the density was approximately 55,000 plants ha ${ }^{-1}$. Maize was planted within half a month after the previous rapeseed crop was harvested. Oilseed rape (Brassica napus L.) was direct sown at a rate of $5.25 \mathrm{~kg} \mathrm{ha}^{-1}$. The density was approximately 35,000 plants ha ${ }^{-1}$, and the variety of oilseed rape is yangguang 2009. The green manure was sown at the same time as the maize, with two rows of Labadou $(40 \mathrm{~cm} \times 8 \mathrm{~cm})$ sown between the wide maize rows. The nutrient content of $100 \mathrm{~kg}$ Labadou was tested to be $2.33 \mathrm{~kg} \mathrm{~N}, 0.30 \mathrm{~kg} \mathrm{P}_{2} \mathrm{O}_{5}$, and $2.53 \mathrm{~kg} \mathrm{~K}{ }_{2} \mathrm{O}$. 


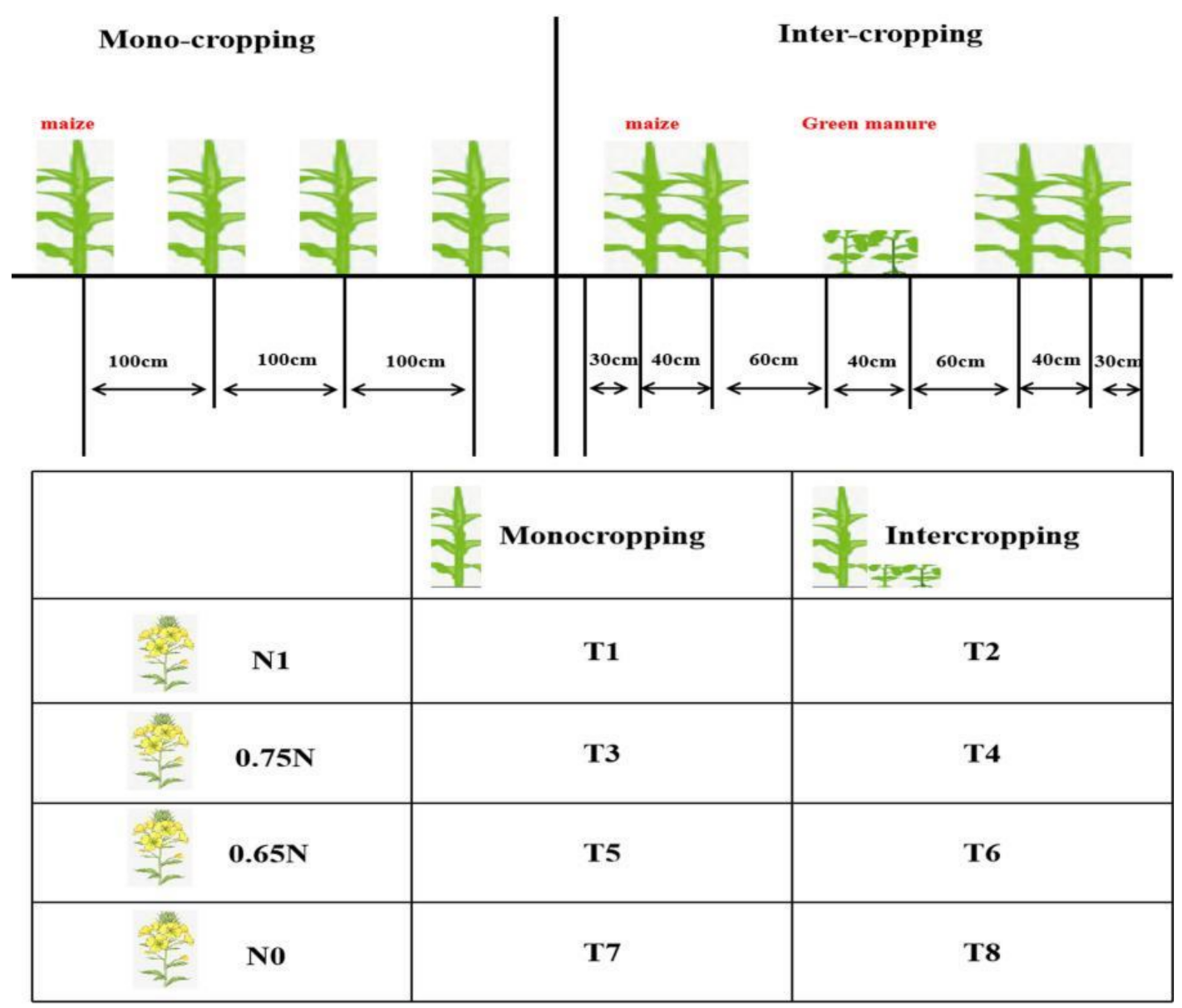

Figure 5. Schematic diagram of maize planting mode and treatment design. Note: T1, T3, T5, T7 represents maize monocropping combined with 100\%, 75\%, 65\%, 0 nitrogen doses in oilseed rape, respectively; T2, T4, T6, T8 represents maize intercropping combined with $100 \%, 75 \%, 65 \%, 0$ nitrogen doses in oilseed rape.

The chemical fertilizer used in the experiment was urea $(46 \% \mathrm{~N})$; superphosphate $\left(12 \% \mathrm{P}_{2} \mathrm{O}_{5}\right)$ and potassium chloride $\left(60 \% \mathrm{~K}_{2} \mathrm{O}\right)$. The same amount of fertilizer was applied in all plots in the maize season $\left(\mathrm{N}: \mathrm{P}_{2} \mathrm{O}_{5}: \mathrm{K}_{2} \mathrm{O}\right.$ was 195:90:135 $\left.\mathrm{kg} \mathrm{ha}^{-1}\right)$. In the oilseed rape season, the application rate of $\mathrm{P}_{2} \mathrm{O}_{5}, \mathrm{~K}_{2} \mathrm{O}$, and Boron fertilizer in all plots was 60,75 and $7.5 \mathrm{~kg} \mathrm{ha}^{-1}$, respectively. The application rate of nitrogen fertilizer was divided into four levels: full standard nitrogen application $\left(\mathrm{N}, 169 \mathrm{~kg} \mathrm{ha}^{-1}\right), 25 \%$ nitrogen reduction $(0.75 \mathrm{~N}$, $\left.126.75 \mathrm{~kg} \mathrm{ha}^{-1}\right), 35 \%$ nitrogen reduction $\left(0.65 \mathrm{~N}, 109.85 \mathrm{~kg} \mathrm{ha}^{-1}\right)$ and no nitrogen fertilizer (N0, $0 \mathrm{~kg} \mathrm{ha}^{-1}$ ) (Figure 5). Three replicates entailed a total of 24 plots. Labadou was returned with the maize straw into the $20 \mathrm{~cm}$ deep soil layer after the maize was harvested as green manure. The full standard quantities of phosphorus and potassium fertilizers were used as base fertilizer, while $60 \%$ nitrogen fertilizer was used as base fertilizer and $40 \%$ applied as topdressing in the budding stage. Field trials with summer maize-winter oilseed rape rotations were carried out from 2018 to 2020.

\subsection{Sampling and Analysis}

Each year, mixed soil samples were collected from the soil surface layer $(0-20 \mathrm{~cm})$ at five points in each plot, using a soil borer, after the oilseed rape was harvested. After removing all animal and plant residues and pebbles, soil samples were air-dried and put through a 100 or 200 mesh sieve for further analysis. Soil properties were determined as follows: total soil organic matter (SOM) using the $\mathrm{K}_{2} \mathrm{Cr}_{2} \mathrm{O}_{7}$ oxidation method; available $\mathrm{N}$ using the Alkaline diffusion method; available phosphorus (AP) concentration using the Olsen method after extraction with $0.03 \mathrm{~mol} \mathrm{~L}^{-1} \mathrm{NH}_{4} \mathrm{~F} 0.025 \mathrm{~mol} \mathrm{~L}^{-1} \mathrm{HCL}$; available $\mathrm{K}$ 
using flame photometry after extraction with $1 \mathrm{~mol} \mathrm{~L}^{-1} \mathrm{NH}_{4} \mathrm{OAC}$, and $\mathrm{pH}(1: 10$, soil to water rate) using a pH meter [47]. The agronomic efficiency of treatments was calculated using the following equation:

$$
A E_{i}=\left(Y_{i}-Y_{C K}\right) / N_{i}
$$

$A E_{i}$ represents the Agronomic efficiency of treatment $i, Y_{i}$ represents the yield of treatment $\mathrm{i}, \mathrm{Y}_{\mathrm{CK}}$ represents the yield of treatment $\mathrm{CK}, \mathrm{N}_{\mathrm{i}}$ represents the nitrogen fertilizer application dose of treatment $i$.

Benefit analysis was calculated as follows: maize and oilseed rape production income, seed and fertilizer cost were calculated according to local agriculture market prices. Labor cost was calculated according to local labor market standards. Total income was the sum of maize and oilseed rape production income; the benefit is total income minus total cost.

\subsection{Statistical Analyses}

Experimental data were analyzed using the SPSS 16.0 software package and Microsoft Office Excel 2010. Analysis of variance (ANOVA) was carried out to determine the differences between the measured parameters for different treatments. The least significant difference (LSD) at $p=0.05$ was used to elucidate any significant differences.

\section{Conclusions}

This study provided a better understanding of green manure utilization in the intercropping planting system to support more effective nitrogen fertilization in the maizeoilseed rape rotation system. Strategies that reduce fertilizer application while maintaining yield are vital for food production methodologies that guarantee agricultural sustainability, particularly in the drought rotation area. Intercropping legume green manure, Labadou, during the maize season and returning it to the field before rapeseed sowing showed obvious substitution effects for rapeseed nitrogen fertilizer. The results of two consecutive years of field trials showed that $25-35 \%$ of nitrogen fertilizers could be replaced by 19-24 $\mathrm{tha}^{-1}$ of legume green manure, a precondition ensuring the seed yield of rapeseed in the experimental site. Intercropping and returning can significantly increase the soil organic matter content of the experimental site and intercropping Labadou with maize is a promising sustainable and low-cost method to improve soil fertility.

Author Contributions: Conceptualization, C.G., X.L. (Xing Liao) and L.Q.; methodology, W.H. (Wei Huang), Y.L. (Yue Li) and Y.L. (Yinshui Li); software, C.G. and C.Y;; validation, C.G.; formal analysis, W.H. (Wei Huang); investigation, W.H. (Wei Huang); resources, J.D., X.L. (Xiaoyong Li) and W.H. (Wenshi $\mathrm{Hu}$ ); data curation, L.Q.; writing—original draft preparation, C.G.; writing-review and editing, M.B.; visualization, M.B.; supervision, X.L. (Xing Liao) and L.Q.; project administration, X.L. (Xing Liao) and L.Q.; funding acquisition, L.X., X.L. (Xing Liao) and L.Q. All authors have read and agreed to the published version of the manuscript.

Funding: This research was funded by China Agriculture Research System of MOF and MARA (CARS-22), the National Key Research and Development Program of China (2018YFD02009).

Institutional Review Board Statement: Not applicable.

Informed Consent Statement: Not applicable.

Data Availability Statement: We would like to exclude this statement as the study does not report any online available data.

Acknowledgments: All the authors are grateful to Chang Haibin who helped perform the field experiment operation.

Conflicts of Interest: The authors declare no conflict of interest. 


\section{References}

1. Walling, E.; Vaneeckhaute, C. Greenhouse gas emissions from inorganic and organic fertilizer production and use: A review of emission factors and their variability. J. Environ. Manag. 2020, 276, 111211. [CrossRef]

2. Kim, D.G.; Thomas, A.D.; Pelster, D.; Rosenstock, T.S.; Sanz-Cobena, A. Greenhouse gas emissions from natural ecosystems and agricultural lands in sub-Saharan Africa: Synthesis of available data and suggestions for further research. Biogeosciences 2016, 13, 4789-4809. [CrossRef]

3. Lu, J.W.; Ren, T.; Cong, R.H.; Li, X.K.; Zhang, Y.Y. Prospects of research on fertilization status and technology of rapeseed in China. Chin. J. Oil Crop Sci. 2018, 40, 712-720.

4. Ndufa, J.K.; Gathumbi, S.M.; Kamiri, H.W.; Giller, K.E.; Cadisch, G. Do mixed-species legume fallows provide long-term maize yield benefit compared with monoculture legume fallows? Agron. J. 2009, 101, 1352-1362. [CrossRef]

5. Madembo, C.; Mhlanga, B.; Thierfelder, C. Productivity or stability? Exploring maize-legume intercropping strategies for smallholder Conservation Agriculture farmers in Zimbabwe. Agric. Syst. 2020, 185, 102921. [CrossRef]

6. Anders, E.J.; Zulu, L.C.; Jambo, E.R. Limits to grain-legume technology integration by smallholder farmers: The case of time-sensitive labor demands and food security primacy in Malawi. Agric. Syst. 2020, 184, 102879. [CrossRef]

7. Piva, J.T.; Bratti, F.; Locatelli, J.L.; Ribeiro, R.H.; Besen, M.R.; Brancaleoni, E.; Schmitt, D.E. Use of winter cover crops improves maize productivity under reduced nitrogen fertilization: A long-term study. Bragantia 2021, 80, e0621. [CrossRef]

8. Cai, A.; Xu, H.; Duan, Y.; Zhang, X.B.; Ashraf, M.N.; Zhang, W.J.; Xu, M.G. Changes in mineral-associated carbon and nitrogen by long-term fertilization and sequestration potential with various cropping across China dry croplands. Soil Till. Res. 2020, 205, 104725. [CrossRef]

9. Kiboi, M.N.; Ngetich, K.F.; Fliessbach, A.; Muriuki, A.; Mugendi, D.N. Soil fertility inputs and tillage influence on maize crop performance and soil water content in the Central Highlands of Kenya. Agric. Water Manag. 2019, 217, 316-331. [CrossRef]

10. Li, L. Intercropping enhances agroecosystem services and functioning: Current knowledge and perspectives. Chin. J. Eco-Agric. 2016, 24, 403-415.

11. Francis, C.A. Multiple Cropping Systems; Macmillan: New York, NY, USA, 1986.

12. Altieri, M.A. The Ecological Role of Biodiversity in Agroecosystems. In Invertebrate Biodiversity as Bioindicators of Sustainable Landscapes; Paoletti, M.G., Ed.; E-Publishing Inc.: New York, NY, USA, 1999; pp. 19-31.

13. Yao, Z.Y.; Zhang, D.B.; Yao, P.W.; Zhao, N.; Liu, N.; Zhai, B.N.; Zhang, S.Q.; Li, Y.Y.; Huang, D.L.; Cao, W.D.; et al. Coupling life-cycle assessment and the RothC model to estimate the carbon footprint of green manure-based wheat production in China. Sci. Total Environ. 2017, 607-608, 433-442. [CrossRef]

14. Li, X.; Liang, Z.; Li, Y.; Zhu, Y.H.; Tian, X.H.; Shi, J.L.; Wei, G.H. Short-term effects of combined organic amendments on soil organic carbon sequestration in a rain-fed winter wheat system. Agron. J. 2021, 1-15. [CrossRef]

15. Zhang, D.; Sun, Z.; Feng, L.; Bai, W.; Yang, N.; Zhang, Z.; Du, G.J.; Feng, C.; Cai, Q.; Wang, Q.; et al. Maize plant density affects yield, growth and source-sink relationship of crops in maize/peanut intercropping. Field Crops Res. 2020, 257, 107926. [CrossRef]

16. Zhang, R.; Mu, Y.; Li, X.R.; Li, S.M.; Sang, P.; Wang, X.R.; Wu, H.L.; Xu, N. Response of the arbuscular mycorrhizal fungi diversity and community in maize and soybean rhizosphere soil and roots to intercropping systems with different nitrogen application rates. Sci. Total Environ. 2020, 740, 139810. [CrossRef]

17. Wang, H.Z. Review and future development of rapeseed industry in China. Chin. J. Oil Crop Sci. 2010, 32, 130-132.

18. National Bureau of Statistics of the People's Republic of China. China Statistical Yearbook; China Statistics Press: Beijing, China, 2018.

19. Gu, C.; Zhang, S.; Han, P.; Hu, X.; Xie, L.; Li, Y.; Brooks, M.; Liao, X.; Qin, L. Soil Enzyme Activity in Soils Subjected to Flooding and the Effect on Nitrogen and Phosphorus Uptake by Oilseed Rape. Front. Plant Sci. 2019, 10, 368. [CrossRef]

20. Pullens, J.; Kersebaum, K.C.; Bttcher, U.; Kage, H.; Olesenad, J.E. Model sensitivity of simulated yield of winter oilseed rape to climate change scenarios in Europe. Eur. J. Agron. 2021, 129, 126341. [CrossRef]

21. Canalli, L.B.D.; da Costa, G.V.; Volsi, B.; Leocadio, A.L.M.; Neves, C.S.V.J.; Telles, T.S. Production and profitability of crop rotation systems in southern Brazil. Semin.-Cienc. Agrar. 2020, 41, 541-2554. [CrossRef]

22. Mupangwa, W.; Nyagumbo, I.; Liben, F.; Chipindu, L.; Craufurd, P.; Mkuhlani, S. Maize yields from rotation and intercropping systems with different legumes under conservation agriculture in contrasting agro-ecologies. Agric. Ecosyst. Environ. 2021, 306, 107170. [CrossRef]

23. Cao, W.D.; Huang, H.X. Ideas on restoration and development of green manures in China. Soils Fertil. Sci. China 2009, 4, 1-3.

24. Dowling, A.; Sadras, V.O.; Roberts, P.; Doolette, A.; Zhou, Y.; Denton, M.D. Legume-oilseed intercropping in mechanised broadacre agriculture-A review. Field Crop Res. 2021, 260, 107980. [CrossRef]

25. Siadat, S.A.; Moradi-Telavat, M.R.; Fathi, G.; Mazarei, M.; Alamisaeid, K.; Mousavi, S.H. Rapeseed (Brassica napus L. var. oleifera) response to nitrogen fertilizer following different previous crops. Ital. J. Agron. 2011, 6, 31-203. [CrossRef]

26. Malik, R.S.; Seymour, M.; French, R.J.; Kirkegaard, J.A.; Lawes, R.A.; Liebig, M.A. Dynamic crop sequencing in Western Australian cropping systems. Crop Pasture Sci. 2015, 66, 594-609. [CrossRef]

27. Sieling, K.; Christen, O. Crop rotation effects on yield of oilseed rape, wheat and barley and residual effects on the subsequent wheat. Arch. Agron. Soil Sci. 2015, 61, 1-1549. [CrossRef]

28. Melander, B.; Rasmussen, I.A.; Olesen, J.E. Legacy effects of leguminous green manure crops on the weed seed bank in organic crop rotations. Agric. Ecosyst. Environ. 2020, 302, 107078. [CrossRef] 
29. Dang, K.; Gong, X.W.; Zhao, G.; Wang, H.L.; Ivanistau, A.; Feng, B.L. Intercropping Alters the Soil Microbial Diversity and Community to Facilitate Nitrogen Assimilation: A Potential Mechanism for Increasing Proso Millet Grain Yield. Front. Microbiol. 2020, 11, 601054. [CrossRef] [PubMed]

30. Xu, Y.G.; Feng, J.Y.; Li, H.S. How intercropping and mixed systems reduce cadmium concentration in rice grains and improve grain yields. J. Hazard. Mater. 2020, 402, 123762. [CrossRef]

31. Costa, N.R.; Crusciol, C.A.C.; Trivelin, P.C.O.; Pariz, C.M.; Costa, C.; Castilhos, A.M.; Souza, D.M.; Bossolani, J.W.; Andreotti, M.; Meirelles, P.R.L.; et al. Recovery of $15 \mathrm{~N}$ fertilizer in intercropped maize, grass and legume and residual effect in black oat under tropical conditions. Agric. Ecosyst. Environ. 2021, 310, 107226.

32. Vanlauwea, B.; Hungriab, M.; Kanampiua, F.; Giller, K.E. The role of legumes in the sustainable intensification of African smallholder agriculture: Lessons learnt and challenges for the future. Agric. Ecosyst. Environ. 2019, 284, 106583. [CrossRef]

33. Liao, J.; Liu, X.; Hu, A.; Song, H.; Chen, X.; Zhang, Z. Effects of biochar-based controlled release nitrogen fertilizer on nitrogen-use efficiency of oilseed rape (Brassica napus L.). Sci. Rep. 2020, 10, 11063. [CrossRef] [PubMed]

34. Gao, S.; Zhou, G.; Rees, R.M.; Cao, W.D. Green manuring inhibits nitrification in a typical paddy soil by changing the contributions of ammonia-oxidizing archaea and bacteria. Appl. Soil Ecol. 2020, 156, 103698. [CrossRef]

35. Zhong, Z.M.; Huang, X.S.; Feng, D.Q.; Xing, S.H.; Weng, B.Q. Long-term effects of legume mulching on soil chemical properties and bacterial community composition and structure. Agric. Ecosyst. Environ. 2018, 268, 24-33. [CrossRef]

36. Duchene, O.; Vian, J.F.; Celette, F. Intercropping with legume for agroecological cropping systems: Complementarity and facilitation processes and the importance of soil microorganisms. A review. Agric. Ecosyst. Environ. 2017, 240, 148-161. [CrossRef]

37. Rodrigues, M.; Withers, P.J.A.; Soltangheisi, A.; Vargas, V.; Holzschuh, M.; Pavinato, P.S. Tillage systems and cover crops affecting soil phosphorus bioavailability in Brazilian Cerrado Oxisols. Soil Till. Res. 2020, 205, 104770. [CrossRef]

38. Wulanningtyas, H.S.; Gong, Y.; Li, P.; Sakagami, N.; Nishiwaki, J.; Komatsuzaki, M. A cover crop and no-tillage system for enhancing soil health by increasing soil organic matter in soybean cultivation. Soil Till. Res. 2021, 205, 104749. [CrossRef]

39. Zhang, Z.; Hu, M.; Bian, B.; Yang, Z.; Yang, W.B.; Zhang, L.M. Full-scale thermophilic aerobic co-composting of blue-green algae sludge with livestock faeces and straw. Sci. Total Environ. 2020, 753, 142079. [CrossRef]

40. Liu, S.; Wang, J.; Pu, S.; Blagodatskaya, E.; Kuzyakov, Y.; Razavi, B.S. Impact of manure on soil biochemical properties: A global synthesis. Sci. Total Environ. 2020, 745, 141003. [CrossRef]

41. Li, F.Y.; Jin, Y.B.; He, S.; Jin, J.W.; Wang, Z.W.; Khan, S.; Tian, G.M.; Liang, X.Q. Use of polyacrylamide modified biochar coupled with organic and chemical fertilizers for reducing phosphorus loss under different cropping systems. Agric. Ecosyst. Environ. 2021, 310, 107306. [CrossRef]

42. Chen, H.; Zheng, C.Y.; Qiao, Y.Q.; Du, S.Z.; Li, W.; Zhang, X.Q.; Zhao, Z.; Cao, C.F.; Zhang, W.J. Long-term organic and inorganic fertilization alters the diazotrophic abundance, community structure, and co-occurrence patterns in a vertisol. Sci. Total Environ. 2021, 766, 142441. [CrossRef]

43. Singh, Y.; Singh, B.; Timsina, J. Crop residue management for nutrient cycling and improving soil productivity in rice-based cropping systems in the tropics. Adv. Agron. 2005, 85, 269-407.

44. Xie, S.W.; Yang, F.; Feng, H.X.; Yu, Z.Z.; Liu, C.S.; Wei, C.Y.; Liang, T. Organic fertilizer reduced carbon and nitrogen in runoff and buffered soil acidification in tea plantations: Evidence in nutrient contents and isotope fractionations. Sci. Total Environ. 2021, 762, 143059. [CrossRef] [PubMed]

45. Fordoński, G.; Pszczókowska, A.; Okorski, A.; Olszewski, J.; Zaluski, D.; Gorzkowska, A. The yield and chemical composition of winter oilseed rape seeds depending on different nitrogen fertilization doses and the preceding crop. J. Elementol. 2016, 21, $1225-1234$.

46. Amossé, C.; Jeuffroy, M.H.; Mary, B.; David, C. Contribution of relay intercropping with legume cover crops on nitrogen dynamics in organic grain systems. Nutr. Cycl. Agroecosyst. 2014, 98, 1-14. [CrossRef]

47. Bao, S.D. Soil and Agricultural Chemistry Analysis; Agriculture Publication Press: Beijing, China, 2000; pp. $355-356$. 